\title{
Kisspeptin receptor (version 2020.4) in the IUPHAR/BPS Guide to Pharmacology Database
}

\author{
Anthony P. Davenport ${ }^{1}$, Janet J. Maguire ${ }^{1}$, Edward J. Mead ${ }^{1}$ and Adam J. Pawson² \\ 1. University of Cambridge, UK \\ 2. The University of Edinburgh, UK
}

\begin{abstract}
The kisspeptin receptor (nomenclature as agreed by the NC-IUPHAR Subcommittee on the kisspeptin receptor [9]), like neuropeptide FF (NPFF), prolactin-releasing peptide (PrP) and QRFP receptors (provisional nomenclature) responds to endogenous peptides with an arginine-phenylalanine-amide (RFamide) motif. kisspeptin-54 (KP54, originally named metastin), kisspeptin-13 (KP13) and kisspeptin-10 (KP10) are biologicallyactive peptides cleaved from the KISS1 (Q15726) gene product. Kisspeptins have roles in, for example, cancer metastasis, fertility/puberty regulation and glucose homeostasis.
\end{abstract}

\section{Contents}

This is a citation summary for Kisspeptin receptor in the Guide to Pharmacology database (GtoPdb). It exists purely as an adjunct to the database to facilitate the recognition of citations to and from the database by citation analyzers. Readers will almost certainly want to visit the relevant sections of the database which are given here under database links.

GtoPdb is an expert-driven guide to pharmacological targets and the substances that act on them. GtoPdb is a reference work which is most usefully represented as an on-line database. As in any publication this work should be appropriately cited, and the papers it cites should also be recognized. This document provides a citation for the relevant parts of the database, and also provides a reference list for the research cited by those parts.

Please note that the database version for the citations given in GtoPdb are to the most recent preceding version in which the family or its subfamilies and targets were substantially changed. The links below are to the current version. If you need to consult the cited version, rather than the most recent version, please contact the GtoPdb curators.

\section{Database links}

Kisspeptin receptor

http://www.guidetopharmacology.org/GRAC/FamilyDisplayForward?familyld=34

Introduction to Kisspeptin receptor

http://www.guidetopharmacology.org/GRAC/FamilyIntroductionForward?familyld=34

Receptors

kisspeptin receptor

http://www.guidetopharmacology.org/GRAC/ObjectDisplayForward?objectld=266

\section{References}

1. Becker JA, Mirjolet JF, Bernard J, Burgeon E, Simons MJ, Vassart G, Parmentier M and Libert F. (2005) Activation of GPR54 promotes cell cycle arrest and apoptosis of human tumor cells through a specific transcriptional program not shared by other Gq-coupled receptors. Biochem. Biophys. Res. Commun. 326: 677-86 [PMID:15596153]

2. Bilban M, Ghaffari-Tabrizi N, Hintermann E, Bauer S, Molzer S, Zoratti C, Malli R, Sharabi A, Hiden U and Graier W et al.. (2004) Kisspeptin-10, a KiSS-1/metastin-derived decapeptide, is a physiological invasion inhibitor of primary human trophoblasts. J. Cell. Sci. 117: 1319-28 [PMID:15020672]

3. Clements MK, McDonald TP, Wang R, Xie G, O'Dowd BF, George SR, Austin CP and Liu Q. (2001) FMRFamide-related neuropeptides are agonists of the orphan G-protein-coupled receptor GPR54. Biochem. Biophys. Res. Commun. 284: 1189-93 [PMID:11414709] 
4. Curtis AE, Cooke JH, Baxter JE, Parkinson JR, Bataveljic A, Ghatei MA, Bloom SR and Murphy KG. (2010) A kisspeptin-10 analog with greater in vivo bioactivity than kisspeptin-10. Am. J. Physiol. Endocrinol. Metab. 298: E296-303 [PMID:19934405]

5. de Roux N, Genin E, Carel JC, Matsuda F, Chaussain JL and Milgrom E. (2003) Hypogonadotropic hypogonadism due to loss of function of the KiSS1-derived peptide receptor GPR54. Proc. Natl. Acad. Sci. U.S.A. 100: 10972-6 [PMID:12944565]

6. Funes S, Hedrick JA, Vassileva G, Markowitz L, Abbondanzo S, Golovko A, Yang S, Monsma FJ and Gustafson EL. (2003) The KiSS-1 receptor GPR54 is essential for the development of the murine reproductive system. Biochem. Biophys. Res. Commun. 312: 1357-63 [PMID:14652023]

7. Hori A, Honda S, Asada M, Ohtaki T, Oda K, Watanabe T, Shintani Y, Yamada T, Suenaga M and Kitada $\mathrm{C}$ et al.. (2001) Metastin suppresses the motility and growth of $\mathrm{CHO}$ cells transfected with its receptor. Biochem. Biophys. Res. Commun. 286: 958-63 [PMID:11527393]

8. Irwig MS, Fraley GS, Smith JT, Acohido BV, Popa SM, Cunningham MJ, Gottsch ML, Clifton DK and Steiner RA. (2004) Kisspeptin activation of gonadotropin releasing hormone neurons and regulation of KiSS-1 mRNA in the male rat. Neuroendocrinology 80: 264-72 [PMID:15665556]

9. Kirby HR, Maguire JJ, Colledge WH and Davenport AP. (2010) International Union of Basic and Clinical Pharmacology. LXXVII. Kisspeptin receptor nomenclature, distribution, and function. Pharmacol. Rev. 62: 565-78 [PMID:21079036]

10. Kobayashi T, Sasaki S, Tomita N, Fukui S, Nakayama M, Kiba A, Kusaka M, Matsumoto S, Yamaguchi M and Itoh F et al.. (2010) 2-acylamino-4,6-diphenylpyridine derivatives as novel GPR54 antagonists with good brain exposure and in vivo efficacy for plasma LH level in male rats. Bioorg. Med. Chem. 18: 5157-71 [PMID:20580563]

11. Kotani M, Detheux M, Vandenbogaerde A, Communi D, Vanderwinden JM, Le Poul E, Brézillon S, Tyldesley R, Suarez-Huerta N and Vandeput F et al.. (2001) The metastasis suppressor gene KiSS-1 encodes kisspeptins, the natural ligands of the orphan G protein-coupled receptor GPR54. J. Biol. Chem. 276: 34631-6 [PMID:11457843]

12. Lee DK, Nguyen T, O'Neill GP, Cheng R, Liu Y, Howard AD, Coulombe N, Tan CP, Tang-Nguyen AT and George SR et al.. (1999) Discovery of a receptor related to the galanin receptors.FEBS Lett. 446: 103-7 [PMID:10100623]

13. Lee JH, Miele ME, Hicks DJ, Phillips KK, Trent JM, Weissman BE and Welch DR. (1996) KiSS-1, a novel human malignant melanoma metastasis-suppressor gene. J. Natl. Cancer Inst. 88: 1731-7 [PMID:8944003]

14. Masui T, Doi R, Mori T, Toyoda E, Koizumi M, Kami K, Ito D, Peiper SC, Broach JR and Oishi Set al.. (2004) Metastin and its variant forms suppress migration of pancreatic cancer cells. Biochem. Biophys. Res. Commun. 315: 85-92 [PMID:15013429]

15. Mead EJ, Maguire JJ, Kuc RE and Davenport AP. (2007) Kisspeptins are novel potent vasoconstrictors in humans, with a discrete localization of their receptor, $G$ protein-coupled receptor 54 , to atherosclerosisprone vessels. Endocrinology 148: 140-7 [PMID:17023533]

16. Messager S, Chatzidaki EE, Ma D, Hendrick AG, Zahn D, Dixon J, Thresher RR, Malinge I, Lomet D and Carlton MB et al.. (2005) Kisspeptin directly stimulates gonadotropin-releasing hormone release via $\mathrm{G}$ protein-coupled receptor 54. Proc. Natl. Acad. Sci. U.S.A. 102: 1761-6 [PMID:15665093]

17. Moriya Y, Kogame A, Tagawa Y, Morohashi A, Kondo T and Asahi S. (2019) Investigation of disposition for TAK-448, a synthetic peptide of kisspeptin analog, in rats and dogs using the radiolabeled TAK-448 suitable for pharmacokinetic study. Xenobiotica 49: 833-839 [PMID:30044673]

18. Muir Al, Chamberlain L, Elshourbagy NA, Michalovich D, Moore DJ, Calamari A, Szekeres PG, Sarau HM, Chambers JK and Murdock P et al.. (2001) AXOR12, a novel human G protein-coupled receptor, activated by the peptide KiSS-1. J. Biol. Chem. 276: 28969-75 [PMID:11387329]

19. Navarro VM, Castellano JM, Fernández-Fernández R, Tovar S, Roa J, Mayen A, Barreiro ML, Casanueva FF, Aguilar E and Dieguez C et al.. (2005) Effects of KiSS-1 peptide, the natural ligand of GPR54, on follicle-stimulating hormone secretion in the rat. Endocrinology 146: 1689-97 [PMID:15637288]

20. Navarro VM, Castellano JM, Fernández-Fernández R, Tovar S, Roa J, Mayen A, Nogueiras R, Vazquez MJ, Barreiro ML and Magni $P$ et al.. (2005) Characterization of the potent luteinizing hormone-releasing activity of KiSS-1 peptide, the natural ligand of GPR54. Endocrinology 146: 156-63 [PMID:15375028]

21. Navarro VM, Fernández-Fernández R, Castellano JM, Roa J, Mayen A, Barreiro ML, Gaytan F, Aguilar E, Pinilla $L$ and Dieguez C et al.. (2004) Advanced vaginal opening and precocious activation of the reproductive axis by KiSS-1 peptide, the endogenous ligand of GPR54. J. Physiol. (Lond.) 561: 379-86 [PMID:15486019]

22. Nishizawa N, Takatsu Y, Kumano S, Kiba A, Ban J, Tsutsumi S, Matsui H, Matsumoto SI, Yamaguchi M and Ikeda $Y$ et al.. (2016) Design and Synthesis of an Investigational Nonapeptide KISS1 Receptor (KISS1R) Agonist, Ac-d-Tyr-Hydroxyproline (Hyp)-Asn-Thr-Phe-azaGly-Leu-Arg(Me)-Trp-NH 2 (TAK-448), with Highly Potent Testosterone-Suppressive Activity and Excellent Water Solubility. J. Med. Chem. 59: 8804-8811 [PMID:27589480]

23. Ohtaki T, Shintani Y, Honda S, Matsumoto H, Hori A, Kanehashi K, Terao Y, Kumano S, Takatsu Y and Masuda Y et al.. (2001) Metastasis suppressor gene KiSS-1 encodes peptide ligand of a G-proteincoupled receptor. Nature 411: 613-7 [PMID:11385580]

24. Ringel MD, Hardy E, Bernet VJ, Burch HB, Schuppert F, Burman KD and Saji M. (2002) Metastin receptor is overexpressed in papillary thyroid cancer and activates MAP kinase in thyroid cancer cells. J. Clin. Endocrinol. Metab. 87: 2399 [PMID:11994395] 
25. Roseweir AK, Kauffman AS, Smith JT, Guerriero KA, Morgan K, Pielecka-Fortuna J, Pineda R, Gottsch ML, Tena-Sempere M and Moenter SM et al.. (2009) Discovery of potent kisspeptin antagonists delineate physiological mechanisms of gonadotropin regulation. J. Neurosci. 29: 3920-9 [PMID:19321788]

26. Seminara SB, Messager S, Chatzidaki EE, Thresher RR, Acierno Jr JS, Shagoury JK, Bo-Abbas Y, Kuohung W, Schwinof KM and Hendrick AG et al.. (2003) The GPR54 gene as a regulator of puberty.N. Engl. J. Med. 349: 1614-27 [PMID:14573733]

27. Semple RK, Achermann JC, Ellery J, Farooqi IS, Karet FE, Stanhope RG, O'rahilly S and Aparicio SA. (2005) Two novel missense mutations in g protein-coupled receptor 54 in a patient with hypogonadotropic hypogonadism. J. Clin. Endocrinol. Metab. 90: 1849-55 [PMID:15598687]

28. Stafford LJ, Xia C, Ma W, Cai Y and Liu M. (2002) Identification and characterization of mouse metastasissuppressor KiSS1 and its G-protein-coupled receptor. Cancer Res. 62: 5399-404 [PMID:12359743]

29. Tomita K, Oishi S, Ohno H and Fujii N. (2008) Structure-activity relationship study and NMR analysis of fluorobenzoyl pentapeptide GPR54 agonists. Biopolymers 90: 503-11 [PMID:18302161]

30. West A, Vojta PJ, Welch DR and Weissman BE. (1998) Chromosome localization and genomic structure of the KiSS-1 metastasis suppressor gene (KISS1). Genomics 54: 145-8 [PMID:9806840]

31. Xing R, Liu F, Yang Y, Cui X, Wang T, Xie L, Zhao Y, Fang L, Yi T and Zheng Rit al.. (2018) GPR54 deficiency reduces the Treg population and aggravates experimental autoimmune encephalomyelitis in mice. Sci China Life Sci61: 675-687 [PMID:29931449] 